\title{
Translation of the Names of Chinese Temples from the Perspective of Culture
}

\author{
Guangqi Zhang ${ }^{1}$ \\ ${ }^{1}$ School of Foreign Studies, Beijing Information Science and Technology University, Beijing, China \\ Correspondence: Guangqi Zhang, School of Foreign Studies, Beijing Information Science and Technology \\ University, Beijing100192, China. Tel: 86-136-0137-6907. E-mail: zgq1605@126.com
}

This paper is sponsored by No.1335027 Science and Research Fund, Beijing Information Science and Technology University.

Received: September 14, 2013 Accepted: October 7, 2013 Online Published: October 13, 2013

doi:10.5430/sass.v1n1p6 URL: http://dx.doi.org/10.5430/sass.v1n1p6

\begin{abstract}
China is a country with a brilliant civilization dating back to several thousand years ago. Her unique and splendid culture casts a great charm on the people of the world. Chinese temples are a treasure of Chinese ancient architecture. The suitable translation of the names of Chinese temples helps the foreign tourists better understand the Chinese culture. Most of “寺”, “庙”, “坛”, “观” have been translated as “temple”, but the culture contained is distinctly different. Therefore, some translation strategies are put into practice, such as, transliteration, free translation, and so on. It is necessary for us to take the flexible translation strategies based on the original meaning of Chinese temples, so as to make the translation full of national characteristics.
\end{abstract}

Keywords: the names of Chinese temples, Chinese culture, the translation strategies

\section{Introduction}

Culture is one kind of social phenomenon, and it is the product of human society; culture is one kind of historical phenomenon, and it is the precipitation of human historical culture. Each nationality, each country has bright cultural characteristics. With its more than 5000 years' long history, brilliant culture and wonderfully preserved beautiful landscape, China attracts more and more tourists from abroad, who are interested in mysterious Chinese traditional culture and hope to experience it. Accordingly, the most important medium for tourists to be familiar with Chinese landscape is the name of scenic spots, and most of them are rich in Chinese unique cultural characteristics. Therefore, the translation of the names of Chinese scenic spots plays an important role in introducing China's splendid culture. A suitable translation can not only make the foreigners get to understand Chinese culture, but also disseminate the Chinese culture to the world.

At present more attention has been paid by some famous authorized experts who have realized the importance of translation of the names of Chinese scenic spots. For example, Jiang Ping, Chang Liang and Wang Zhijiang have introduced the translation of Chinese scenic spots of some areas; while Lu Guofei, Yang Sigui and Ran Longsen have introduced the translation of Chinese scenic spots abiding by some specific translation theories, moreover, Lin Yuhua has introduced the translation of Chinese scenic spots in the perspective of culture. However, few of them have focused on the translation of the names of Chinese temples from the perspective of culture.

\section{Translation Theories}

The existence of cultural differences brings certain difficulties to the cultural exchange. It is also one of the biggest barriers in the translation. In the process of translating, the translators should understand not only these two languages thoroughly, but also the cultural differences between them profoundly. Many famous scholars have proposed a number of translation theories, but a few of them have been regarded as the Bible among numerous scholars.

\subsection{Functional Equivalence}

Nida's famous translation theory is the Functional Equivalence, which says that, 
The functions of language are of two basic types: psychological and sociological. The psychological functions may be described as the means by which people negotiate with reality, and the sociological functions can be said to be those ways by which people negotiate with other persons. The psychological functions may be regarded as essentially internal or subjective, and the sociological functions as external and interpersonal. (Nida, 1995)

However, any two languages are impossible to be coordinated completely. Therefore, it is impossible to reproduce the two kinds of meanings of the original text completely. First, because the cultural differences produce the contradiction in the translation process, the word meaning or the image meaning must obey the implied meaning. Second, the image meaning of the original text cannot be found in the target language. Sometimes the images are the same but the implied meanings are actually different. In this situation, what the translators need to consider first is the accurate expression of the implied meaning. The images of the original text should be changed into other images that the foreign readers are familiar with.

In his Language, Culture, and Translating, the adequacy of translations has traditionally been judged on the basis of the correspondence in lexicon and grammar between the source and target languages. Additionally functional equivalence has been stated primarily in terms of a comparison of the way in which the original receptors understood and appreciated the text and the way in which receptors of the translated text understand and appreciate the translated text. (Nida, 1995) Therefore, it is known "functional equivalence" in terms of a range of adequacy, "equivalence" can not be understood in its mathematical meaning of identity, but only in terms of proximity is on the basis of degrees of closeness to functional identity, which means on the basis of degrees of closeness to functional identity. (Nida, 1995)

\subsection{Functional Equivalence from the Perspective of Culture}

Since culture is defined succinctly as "the totality of beliefs and practices of a society," nothing is of greater strategic importance that the language through which its beliefs are expressed and transmitted and by which most interaction of its members takes place. Nida pays more attention on this phenomenon which is also the foundation of his famous translation theory - functional equivalence.

The most important part in translation is that the translating language with another coordinated language is to carry on each kind of transformation, transmitting the precise information of the original text for the readers, which aims to achieving Equal Reaction of Readers. The translation should be "the most appropriate, most natural equivalence of the source language." As Nida said, "the best translation does not sound like a translation". (Nida, 2003) On the other hand, the cultural information contained in the translation should be understood by the readers. In his theory, the purpose of the acceptors who read the translated text is to know different culture. Therefore, the translated text should retain different manner to express the culture and language so as to cause cultural communication and enrich the target culture and language. He points out that in translation people should focus on form equivalence, because it also expresses the meaning of the source language if one changes the form that means the meaning is altered. There are four translation strategies which are based on the Functional Equivalence from the perspective of culture: transliteration, free translation, translation plus the meaning law and translation with the law of explaining.

Transliteration refers to the unit with phoneme retained in the source language text to highlight the pronunciation of the main function of language translation methods. It is the practice of converting a text from one writing system into another in a systematic way, also the transformation of text from one script to another, usually based on phonetic equivalencies. When it is hard to find the correct expression of names and of some new ideas or phenomenon, transliteration is a better translating strategy to introduce these kinds of words to the language of version, especially translating the names of scenic spots from Chinese into English. It is also a way to create new words into target language with different culture which includes the proper noun relative with culture in the source language. Transliteration is the better way to translate these proper nouns into another language.

Free translation means a rough translation which gives the general meaning without translating the text word for word; and it is only to reserve the original opinion rather than the original form. It is used when the difference is great between the two kinds of culture. From the aspect of intercultural communication, free translation emphasizes the relative independence between the culture system of version and the original language cultural system. The Functional Equivalence which is proclaimed by Eugene A. Nida highly praises free translation. Therefore, we must emphasize again that the translation should not only include the ideological content, but also the form of language. When translating the name of scenic spots, we should focus on the equivalence of lexical grade which goes after the equivalence of expressed meaning. 
Based on the differences of culture, sometimes people can not understand clearly another culture which is distinguished from them, the author introduces two methods to solve this problem that is translation plus the meaning law and translation with the law of explaining. When translating the name of scenic spots, the first one is to translate these into pinyin, and at the same time to explain the name of scenic spots with English, while the second one is to focus on explaining the meaning of the name of scenic spots. Transliteration and explanation avoids either the shortcoming of transliteration lack of expressed meaning or that of free translation which may lead to misunderstanding to target receivers. However, transliteration and paraphrase offers the clear understanding for the target receivers. These four methods are main translation strategies to introduce the name of Chinese scenic spots to the world.

\section{Translation in Functional Equivalence}

The translation is the transformation between two languages, and the close relationship between culture and language requires the cultural transformation. Therefore, the names of Chinese temples should be translated appropriately so that foreigners can understand Chinese culture and the origin of the name of Chinese temples pellucid. The four main factors which influence the names of Chinese temples are listed as follows.

\subsection{Translation of the Names of Chinese Temples in Buddhism}

Since ancient times, the main belief in Chinese nation is Buddhism and Taoism, while Buddhism is one of the three major religions of the world (Buddhism, Christianity and Islam), which is first popularized along Ganges River of central India by Sakyamuni. It can be dated from the 6th century BC. "Buddha" means the enlightened one, and "Creed" can be understood as religion or education. So "Buddhism" means that the Buddha publishes a common education. Buddhism pays great attention to the progress and the consciousness of human mind. Only people without greed, anger and stupidity can be divorced from birth and death, and then they are not irritated. The aim of Buddhists is to understand the truth of "Self" and beyond all troubles through the education of Buddha, becoming Buddha or arhat.

Tibetan Buddhism is an indispensable part of Chinese Buddhism. It is the localized Buddhism in Tibet and has a long history; it developed fast since the ruling class of Yuan Dynasty pushed it forward and entitled the religious leader of Tibet as Dharma King to unite the religion and government into one. In its development it has former features of its own and spread over a vast area. Some call it "Lamaism", or "Tibet Buddhism", "Buddhism of Tibet", but Tibetans call it "Sangjiequnu". "Lama" is the pronunciation of Tibetan, meaning "superior master" or "superior man". The ordinary monks were called "Drakpa" in Tibetan, while "lama" was only for the temple abbots or adept monks. (Later "Drakpa" are also called "lama".)

Many Chinese scenic spots are built on the influence of Buddhism, such as three cave temples, namely Mogao Grottos, Yungang Grotos, and Longmen Grottos, whereas Dazu rock carvings in Chongqing City, and some famous temples in China. Here are some examples to demonstrate it abiding by the Functional Equivalence theory with four translation strategies: transliteration, free translation, transliteration and explanation, transliteration and paraphrase.

\subsubsection{Transliteration}

1) Qianxi Temple (潜溪寺): The name means "hidden stream" since water ran out like a stream during the carving. In Buddhism, "Amita" means "infinite light" and "eternal life", and it is a key Buddha worshipped by the Pure Land school of Mahayana Buddhism. Sutras say he is the holy god of the west world of ultimate happiness, and anyone who recites his name exclusively as a daily practice of Buddhism will be guided by him to this world of ultimate happiness on one's death.

2) Shenghou Temple (圣寿寺): The temple is an ancient temple of Buddhism that has five big halls in a series laid out in harmony with the rising of the mountain. It was first constructed in South Song Dynasty, then damaged in the war in Yuan Dynasty, and rebuilt in Ming Dynasty. Shengshou Temple was built by Monk Zhao Zhifeng in South Song Dynasty to commemorate their founding master Liu Benzun. In later Tang Dynasty, Liu Benzun, an esoteric Buddhist, had built a temple in Guanghan, which was praised by Emperor Shenzong of Song Dynasty, who awarded it the name "Benzun's Hall of Shengshou (Holy Longevity)", and Liu Benzun used the same name for this temple as well. Some people also call it Holy Longevity Temple. (Luo, 2004)

3) Dule Temple (独乐寺): Legend has it that it was the place where An Lushan, a local official in charge of the military and administrative affairs of several prefectures in the Tang Dynasty, held a rally to pledge resolution before rising in rebellion. As he was fond of enjoying happiness by himself rather than with other people, it was named Dule (Enjoying Happiness by Oneself) Temple. (Zhang \& Hu, 2007) 
4) Huayan Temple (华岩寺): It was originally known as “Huayan Cave," attracting worshippers early in the Tang Dynasty. But the earliest documented record of it is dated between 1587-1599 during the Wanli reign period of the Ming Dynasty, when Yang Yi of the gentry invited Wuquan, a monk from Luzhou, to raise funds together to build a temple beside the Huayan Cave, and named "Qiu'ai Temple." (He, 2006) In the $7^{\text {th }}$ year of Emperor Kangxi of the Qing Dynasty (1668), Monk Shengke built Huayan Temple at the site, about 100 meters away from the cave. The buildings surrounded by the temple are arranged in a step-like formation, solemn and graceful. They all have corridors and railings. Place yourself in one of the buildings and you will feel completely tranquil and relaxed. Over the past twenty years, the Buddhist school established in Huayan Temple has gained a good reputation.

5) Guiyuan Zen Temple (归元禅寺): It is a famous Zen shrine at the front of Cuiwei Peak in Hanyang. What distinguishes it from other temples is that its layout resembles a monk's robe. The temple was founded by Bai Guang and Zhu Feng, who were brothers before becoming monks. They traveled from Zhejiang to the Xingguo Temple in Hanyang, where they studied Buddhist scriptures and did charitable work among the local people, for example, treating the sick. Local businessmen, including Sun Yaoguang and Dai Tiancheng, were moved by their virtues, and raised the money to build the Guiyuan Zen Temple. Zen means "meditation and abandoning evil." "Guiyuan" originated from the Surangama Samadhi Sutra, meaning "entering nirvana."

6) Xumifushou Temple (须弥福寿之庙): It is in the north of the Mountain Resort and to the west of the Temple of Universal Peace. It was the temporary residence of the Sixth Bainqen Lama. In the Tibetan language, "Xumifushou" means "Tashilhunpo," in which "Tashi" means happiness and longevity, and "lhunpo," means "Sumeru." (Du \& Du, 2007) In the 45th year of the Qianlong reign period (1780) of the Qing Dynasty, the Sixth Bainqen Lama took 13 months and traveled over 10,000 kilometers to Chengdu to offer birthday congratulations to Emperor Qianlong. The emperor, who paid great attention to this event, studied the Tibetan language hard, and issued an order that a temporary palace residence be built according to the Tashilhunpo Monastery in Xigaze where the Bainqen Lama lived. It took a year to finish the construction of the temporary residence for the honored guest where Bainqen Lama resided and preached Tibetan Buddhism.

\subsubsection{Free Translation}

1) Twin Tree Temple (双林寺): It was originally named Zhongdu (Central Capital) Temple, located in Qiaotou (Bridgehead) Village, $6 \mathrm{~km}$ southwest of Pingyao. The temple was first built in the early North Wei Dynasty, but the present halls and houses are mostly that of Ming and Qing Dyansties. Although large and grandiose when built at North Wei Dynasty, it was later burned down in war. In Song Dynasty, the temple was rebuilt and renamed as Twin Trees (Shuanglin) Temple in association with Buddha's Nirvana under the twin sara trees.

2) White Horse Temple (Baimasi in Chinese) (白马寺): It is the earliest temple of Buddhism in China. The legend is that Liu Zhuang, Emperor Ming of East Han Dynasty, had a dream in which he was a gold god from the west flying in his palace. He then sent 18 men to the west land to look for Buddhism. In Rouzhi Kingdom (around present Afghanistan) the envoys met Kashyapamtanga and Dharmaraksha, two eminent monks from India, who accepted their invitation and came to Luoyang, taking with them 42 Buddhist sutras carried on the back of a white horse, and the emperor built the White Horse Temple specially for the two masters to translate the sutras. The temple seats between Mt Mang in the north and Luo River in the south, grand and solemn as a highly admired site to both Buddhists and others either at home or overseas. (Luo, 2004)

3) Prominence Temple (xiantongsi) (显通寺): The temple was first constructed in the Yongping reign period (58-75) of the Eastern Han Dynasty; it is one of the oldest temples in China. Legend has it that once Bodhisattva of Wisdom preached Buddhism here, and now it is well known for the Immeasurable Hall, Bronze Hall, bronze pagoda and other bronze cultural relics. The Bronze Hall was first constructed in the 37th year of the Wanli reign period (1609) of the Ming Dynasty, five meters high. It is said that over one million jin (one jin $=0.5$ kilogram) of bronze was collected from 10,000 families of the 13 provinces to build this hall. The hall has double eaves and a roof in xieshan style (a traditional style of Chinese palace architecture, fully hipped on both sides, and half-hipped at the ends, so that an upper gable is left exposed). The four-side upper story has six doors, and the four-side lower story has eight doors, each door decorated with beautiful flower patterns. The whole bronze hall is majestically decorated and exquisitely cast. This bronze building is rare in China.

4) Zhaohua Temple (昭化寺): It is also known as Xida Temple, which was built in the Zhengtong reign period (1436- 1449) of the Ming Dynasty, remains in good shape. It is located on the north side of Xida Street, Huai'an Town. According to historical records, in 1397 Yongqing Buddhist Temple was built, and in 1445 it was expanded as a base for disseminating Buddhism. The Ming court bestowed on the temple a horizontal board carrying the inscription "Zhaohua Temple." 
5) Jokhang Temple (大昭寺): The temple seats in the center of Lhasa City, first constructed in 647 , the $21^{\text {st }}$ year of Zhenguan Period of Tang Dynasty. It is the oldest wooden building in Tibet, and the primary statue of Sakyamuni was brought here by Princess Wencheng. The honor of Lhasa as a sacred land owns much to this statue. The temple was first called Rasa a term that gradually became "Lhasa" as the present name of the city. After its construction, the temple was renovated or expanded once and again in the following dynasties of Yuan, Ming, and Qing, and finally stands there with grandeur as is seen today. (Luo, 2004) Here, it is wiser to translate “大昭” into Jokhang, because we have known the temple is based on Tibetan Buddhist and Jokhang is a Tibetan word, which helps foreigners to get to know that this scenic spot is related to religion.

6) Lama Temple (雍和宫): Located in Beijing, the Yonghe Palace was first constructed in the 33rd year of the Kangxi reign period (1694) of the Qing Dynasty, and was turned into a lamasery in the ninth year of the Qianlong reign period (1744), which later became the Qing government's administration center for national affairs related to Lamaism. The Yonghe Lamasery is an architectural complex showing the characteristics of the Tibetan, Han, Mongolia and Manchu ethnic groups. It is the largest and most gorgeous lamasery of Gelug Sect of Tibetan Buddhism in the inland. (Du \& Du, 2007) In 1744, it was formally converted into a Lamasery but it retained the name: "Yonghegong", the Palace of Harmony and Peace. It is no doubt that by translating “雍和宫” into "Lama Temple", foreigners can get to know that this scenic spot is related to religion. So it is unnecessary to translate it by other strategies.

\subsection{Translation of the Names of Chinese Temples in Taoism}

Taoism is a traditional religion in China, originated from the primitive witchery, theology, and the philosophy of Lao $\mathrm{Zi}$ and Zhuang Zi before Qin Dynasty the quest for immortality and Huanglao Dao of the Qin and Han dynasties.

In the traditional Chinese culture, Taoism is considered as various theories and practices. Taoism looks "Tao" and "Virtue" as the basic believes. And it is believed that "Tao" is the origin of the universe, and master of the omnipresence. It is all-embracing, and everything is from "tao" evolved. "Virtue" is the expression of "Tao". Taoism pursues "forever", and the idea of Taoism is that one's destiny can depend on him, as long as he keeps himself in good health, he will be an immortal. Therefore many cultivation methods are adapted, the most famous way is Lian Dan. Taoism pursues the "oneness of heaven and man" and the "way of nature"; thus the building groups managed best to keep the original topography of Wudang Mountain. The types of the buildings are varied, and the building materials are basically local. The structures, decorations, and furniture, are all exquisitely made, not only reflecting the amazing advancement in technology and architectural art, but also successfully manifesting the intended conception of "brilliant buildings among Fairy Mountains". (Luo, 2004) Taoism adopted in its regimen the ancient practice of fetal respiration, breathing, physical exercise, abstinence for good health, which in nature is the exploration for the secret of life. In a sense, Wudang Kung Fu is the consequence of this exploration by Wudang Taoism.

In the past thousands of years, a number of historic figures took hermitage here to be a true being, and countless pilgrims and visitors of admiration pay their respect and worship every year. Taoism has affected on not only Chinese people's thinking mode, but also the architectural structures in China. As for that reason many emperors have built Taoism temples to pursue forever. Numerous examples will be shown as followed:

\subsubsection{Transliteration}

Huanglong Temple (黄龙寺): The area in which travertine landscapes are most concentrated is Huanglonggou (Yellow Dragon Gully). This giant golden dragon, measuring approximately 3.6 kilometers in length, is the world's largest-scale karst landform, which also has the most complete structure and the most peculiar shape. Legend has it that, in ancient times, the Yellow Dragon helped Yu the Great, China's water-control hero, to successfully prevent flooding. The Yellow Dragon then came to Huanglonggou to cultivate vital energy and became an immortal. Later generations referred to him as Huanglong Zhenren ("the Immortal Yellow Dragon"). To commemorate him, the local people built a Taoist temple, called the Ancient Huanglong Temple. The Ancient Huanglong Temple is an important site for investigating the development of Taoist culture through the ages.

\subsubsection{Free Translation}

1) Qingxu Temple of Taoism (清虚观): This is the largest Taoist temple in Pingyao, on East Street, first built in 657. The grandson of Wang Chongyang, founder of Quanzhen (Total Reality) sect of Taoism, was said once the head of the temple, and worshipers of today still crowd in with piety at this temple of over 1,000 years old. It has three courtyards that covers 6,000 $\mathrm{m}^{2}$, and remodeled or enlarged in Song, Yuan, Ming, and Qing Dynasties, therefore the buildings are in different styles of these periods. 
2) Morning Sun Temple (朝阳观): In the year 1551- 1557, the Morning Sun Temple was dug into the cliff. It got its name from being the recipient of the first rays of the morning sun around the area. On the second day of the Ming Dynasty, a black light shot into the sky from here, and an earthquake followed the very next day. Although the temple has experienced repeated destruction, its fame as a wonder of the area beyond the Great wall has spread far and wide. (Xiang, 2006)

\subsubsection{Transliteration \& Explanation}

Yuanhe Temple (Temple of Fundamental Harmony) (元和观): The temple is in the south of Sage Encounter Palace. According to Taoist classics, after Lofty God of Xuanwu obtained full revelation and became a god, he was in charge of "Yuanhe Qianxiao Department", and that is why the temple was named "Yuanhe". In Taoism, "yuanhe" refers to the essence liquid produced in the alchemy of internal elixir, and "qian" means "exile" while "xiao" refers to punishing tools such as chains and handcuffs. In fact, Yuanhe Temple was the Taoist disciplines; therefore the design was awesome and deterring. The disciplines of Taoism are many as nearly a thousand in number, detailed with penalties for any kind of violation of the disciplines. As the executive organ of Wudang Taoism, Yuanhe Temple had a special significance in the development of Taoism. (Luo, 2004)

From what has been explained above, we understand that the word "temple" can be translated into different Chinese characters, such as “寺” and “观”.

\subsection{Translation of the Names of Chinese Temples in Natural Worship}

Natural worship is the earliest religious form in our society, which means to worship those whom are regarded with life, will and powerful ability. It appeared in the Neolithic Age; and it was original form of Chinese people's traditional thinking mode - harmony between men and nature. At that time people have had a tendency to regard natural world and natural forces as super nature.

The reason why the natural worship appears is that primitive men think many natural phenomenon, including heaven, earth, sun, moon, star, mountain, stone, sea, lake, river, fire, wind, rain, thunder, snow, rainbow, etc. show the existence of life, will, emotion, spirituality and unusual ability, which will affect the existence of human beings and their fate. Therefore, the basic form of expression is personification or sacred natural objects and natural forces and other celestial bodies and natural phenomenon, that is to say those things had been worshipped for blessing. In fact, "China enjoys a unique position in religious thought," as Parker says, the natural worship is related to human beings" society.

... because samples of all religions have been presented to her in turn, and it is surely very much to her credit that at no period of her history have the ruling powers 'in being' ... refused hospitality and consideration to any religion recommended to them purely as such. (Juliet, 2009)

In general, the thing which has been worshipped is one of the most damaging natural objects and natural forces that impact on the survival of the tribe and the existence of the social products in the area. The original natural worship later becomes a more abstract natural worship due to the development of its worshipping objects of the gods, which include the god of celestial bodies, the god of all things, the god of four seasons, the god of weather and other different styles which relative to natural spirits. Natural worship has become one of religious beliefs since ancient society.

\subsubsection{Transliteration}

1) The Temple of Mazu (妈祖庙): The temple of Mazu, the Goddess of Sea, on one of the many docks in Zhenyuan. But Zhenyuan is an inland town, far away from the sea. A close study reveals that in the past, many merchants came here from Fujian Province. Fujian merchants erected the temple of Mazu in Zhenyuan for they wished their Goddess of Sea to bless them for their merchandise shipment on the rivers. The annals of Zhenyuan also record a past magistrate of the county who was a native of Fujian. It was under his sponsorship that fund was raised among the Fujian businessmen in Zhenyuan for the construction of the temple of Mazu which is so common a sight on the Chinese eastern coast, Taiwan Province and even many places of overseas Chinese communities in Southeast Sea.

2) Dai Temple (岱庙或山神庙): Located in the northwest of Tai'an City, Dai Temple is also called Temple to the God of Taishan, and it the place where the emperors in the past dynasties offered sacrifice to the God of Taishan. It houses a masterpiece of Taoist painting dated from 1009 AD. and entitled "The God of Taishan Making a Journey". (Gong \& Zhang, 2006)

3.3.2 Free Translation

1) Town God Temple (城隍庙): The temple is on the street of Town God Temple, facing the county office on the 
other side. This arrangement of "Town God left and County Office right" conforms to the ritual idea of "co-governing by man and god". It covers over 7,300 $\mathrm{m}^{2}$, consisting of the temples of Town God, God of Wealth, Kitchen God, and courtyard of Taoism. The temples of God of Wealth and Kitchen God are at the east and west side of Temple of City God and the three in one courtyard is a peculiar format that "Several gods share one temple courtyard to enjoy worship together." The temple is well known for its excellent glaze decoration, wall paintings and wood carvings of Qing Dynasty.

2) The Temple of Heaven (天坛): The Temple of Heaven, built in 1420 AD, was where emperors of the Ming and Qing dynasties offered sacrifices to the Gods of Heaven and Earth. The Temple of Heaven was originally called Tianditan (the Temple of Heaven and Earth). In 1530 AD, the Ming Dynasty Emperor Jiajing built a temple in the northern suburbs of Beijing specifically to offer sacrifices to the God of Earth. Thus, this place became the venue to worship heaven and pray for a good harvest, and was renamed as the Temple of Heaven. (Juliet, 2009) The main architectural structures in the Temple of Heaven from south to north include the Circular Mound Altar, Imperial Vault of Heaven, Hall of Prayer for Good Harvests and Hall of Imperial Heaven. The northern part of the temple is circular, while the southern part is square, implying that "the heaven is round and the earth is square". This curve, however, was considered necessary, like the semi-circular brick screen behind Chinese graves, to prevent the ingress of evil influences from "the Northern abode of Darkness." With respect to planning, construction and environment, the Temple embodied the concept of the ancient Chinese Yin-Yang and the ideology of the Five Elements. The created an ideal environment of tianren ganying (heavenly response), bearing the reverent feelings and earnest expectations that ancient people extended towards heaven. (Juliet, 2009)

3) The Temple of Agriculture (先农坛): On the other side of the broad street leading from the Ch'ien Men to the Yung Ting Men stands the Temple of Agriculture (Hsien Nung T'an) - a counterpart of the Temple of Heaven but on a smaller scale - dedicated to the cult of Shen Nung, a prehistoric emperor known as the First Farmer, whose "special talents enabled him to understand the surreal world and exercise great influence over it," and to whom are ascribed the invention of the plough, the discovery of the medicinal properties of plants and the establishment of the first markets. This temple also has a deep significance in a country primarily agricultural where, as Emerson says, the people believe that "all trade rests at last on the farmer's primitive activity" and honors his calling; where the sovereignty himself confirmed the high, idealistic position of the cultivator of the soil by offering solemn worship to the fruitfulness of the earth. (Juliet, 2009)

Other examples are given here, for instance, the Temple of God of Wealth (财神庙), the Temple of Kitchen God (灶 神庙), etc. These temples are based on the natural worship usually being structured for a venue to worship the Gods in the Heaven or at the Earth praying for blessing, harvest, safety or wealthy, which are translated as “庙”or “坛”.

\subsection{Translation of the Names of Chinese Temples in Personal Worship}

Personal worship aims to worship someone as ancestral, patriarchal or even national preventative by structuring some traditional typical erections to perform the annual sacrifices in honor of him or her. What is more, the persons can be the ancestors and national heroes or heroines in Chinese history or legend stories, the outstanding persons in Chinese history or original family notes or heroes or heroines in Chinese popular legend. Over the centuries, people have structured thousands of immortal architectural buildings to honor the persons and hand their spirit down for generations.

\subsubsection{Transliteration}

Guan's Temple (关林): Literally means Guan's World, it is said the tomb of the head and a carved wooden body of Guan Yu, a highly reputed general of Shu Kingdom in the Three Kingdoms Period, who, soon after his death, is regarded as the protector and the God of Loyalty in Chinese legend.

See more examples: Guan Di Temple (关帝庙), Guan Yue Temple (关岳庙) and so on. If the temple is somewhat relative to Chinese traditional thinking - Confucius, it is better to translate into “庙”, but the temples which are based on Chinese popular legend should be translated flexibly according to the public.

\subsubsection{Free Translation}

1) The Temple of Confucius (文庙或孔庙): It is located in the city proper of Qufu, where the people worship Confucius, who was a famous thinker, statesman, educationist, and the founder of Confucianism at the end of the Spring and Autumn period (770-476 BC). According to historical records, Lord Ai of the state of Lu turned the three old houses of Confucius into the "Temple of Confucius" in the second year after Confucius's death. After the Western Han Dynasty (206 BC- 25 AD), the emperors of the successive dynasties kept giving Confucius posthumous titles and honors. As a result, his temple was continuously renovated and expanded until it became a magnificent 
architectural complex. Legend his it that when the emperor came here to pay homage to Confucius, the pillars would be covered with red clothes, because they are even larger and more magnificent than the dragon pillars in the imperial palace. With carved beams and painted pillars, the resplendent Temple of Confucius is the largest and oldest temple built for a scholar in Chinese history; hence it is a wonder in the Chinese architectural history, and even an architectural wonder in the world. ( Du \& Du, 2007)

2) Prince Yue's Temple (岳王庙): Yue Fei (1103- 1142), honored as the most famous patriotic general in Chinese history, was buried at the Temple of Prince Yue that sits against the Qixia Ridge to the north and faces West Lake to the south. His tomb lies behind a tall red wall amid straight Chinese parasol trees. Local people held General Yue in respect for his patriotism and lamented his death at the hands of the despicable officials. His lofty aspirations for recovering the lost land from the enemy were left unfulfilled. After the general was murdered, Wei Shun, a prison guard, secretly removed his body from the city and buried it outside the Qiantang Gate. Twenty one years later, General Yue was exhumed and his remains were reburied in the Zhiguo Temple at the front of the Qixia Ridge. People flocked there to pay him homage. The temple was later renamed Prince Yue's Temple.

3) Temple of Marquis Wu (武侯祠): Temple of Marquis $\mathrm{Wu}$ is a memorial temple in honour of Zhuge Liang (181-234 AD) Wu Xianghou Prime Minister of Shu Han in the Three Kingdoms Period. It has been over 1500 years since it began to build the temple at the end of the Western Jin Dynasty. Early in the Ming Dynasty, Wuhou temple which merged Han Zhaolie Temple in honour of Liu Bei (161-223 AD), covers an area of over 30 thousand square metres. In the temple there is one hall after another with rigorous distribution, in the dimness of bluish cypresses and a solemn atmosphere. Imperial Tomb of Liu Bei is 12 metres in height. The temple houses 47 statues of Liu Bei, Zhuge Liang and other civil officials and senior generals of the State. Among these precious historical relics the most famous are Zhuge Liang's "Letter to the Throne Before Expedition" in national hero Yue Fei' handwriting and the Tablet of Triple Consummation (that is calligraphy, handwriting and engraving). (Lin, 2008)

Most of these temples with personal worship are translated into“庙” or “祠”in the influence of Confucius, especially the place for worship ancestors, gods or virtuous person.

\subsubsection{Transliteration and Explanation}

The Memorial Temple of Qu Yuan (屈原祠): Zigui is the hometown of the great Chinese poet Qu Yuan. Frustrated at being unable to realize his political ideals, Qu Yuan threw himself into the Miluo River in 278 BC. Legend has it that a big fish from the Dongting Lake in Hunan carried his dead body to Zigui, where people buried him in a sandy beach between Zigui and Xiangxi. The sandy beach was then called Quyuantuo (Bay of Qu Yuan). Later, the people of Zigui built an ancestral temple, bronze statue and memorial hall and tomb to commemorate the poet. The memorial temple of Qu Yuan (339- 278 BC) is located by the Xiangxi Brook. A great politician and poet, Qu Yuan held a senior position in the court of King Huai of $\mathrm{Chu}$, but was slandered and forced into exile. After the troop of Qin seized the Chu capital, he drowned himself in the Miluo River in today's Hunan. In 1953, the World Peace Council named $\mathrm{Qu}$ Yuan, together with Copernicus, Francois Rabelais and Jose Marti, as four world cultural celebrities. Qu Yuan is remembered for his patriotism as well as his literary achievements, such as his poet Li Sao (lament at Parting), Zigui County abounds in stories and historic sites relating to Qu Yuan, among them his presumed birthplace Xiangluping, the well he dug at Zhaomian, the field he once worked in Qu Field, the Reading Cave, where he studied, and Qu Yuan Bay, where the divine fish brought Qu's remains ashore after his suicide.

Most of the temples in honor of virtuous and outstanding persons are translated into “祠”.

\subsubsection{Transliteration and Paraphrase}

Jingyi Hall of the Ancestral Temple of the Huang Clan in Huangcun Village (黄村黄氏宗祠经义堂): It is 35 kilometers north of Wuyuan County and was built during the Kangxi reign of the Qing Dynasty. The hall was built with 100 fir columns, so it is also called "the 100-column ancestral hall." The roof beam bears delicate carvings and is decorated with traditional paintings of auspicious things in China. It was once exhibited in photos in Paris in 1982 and shocked the viewers. (Du \& Du, 2007)

This strategy gives a comprehensive understanding to foreigners, which is the best way to introduce Chinese scenic spots and Chinese culture. We translate the temples boring relationship to patriarchal clan into “宗祠”.

\section{Conclusion}

The source is distant and the stream is long in Chinese culture. As for the language, the influence of culture is essential, and the cultural awareness should be taken into consideration in the process of translating. The names of scenic spots are the most important part in tourism English, and there are numerous temples which are based on 
different cultural factors. A good name is not only a window to introduce the Chinese culture, but also a shortcut to improve the development of tourism. Only if we understand the culture of Chinese temples well can we translate them suitably and accurately. Therefore, the study on translating the name of Chinese temples in the perspective of culture is important and urgent.

Chinese temples are classified in his paper into four categories which are Buddhism, Taoism, Natural worship and Personal worship in the point view of culture; thereby it is easy to find out that the English word "temple" can be translated into eight different Chinese characters: “寺”, “庙”, “宫”, “观”, “坛”, “林”, “祠”, “宗祠”. In general, “寺” and “观” usually have some religious background, while “坛” and “庙” are structured for a venue to worship the gods of Heaven or Earth and the soul of ancestors. (Yu, 2007) “祠” is a group of buildings which is structured in feudalism, for honoring outstanding ancestors by social public or certain class, however, “宗祠” is also named “祠 堂” in patriarch system, which is the place for a certain clan to enshrine and worship their ancestors or the place for discussing family official business, studying and implementing family law.

For the translation of the name of Chinese Temples, some basic skills and strategies should be put into practice. It is necessary to choose the Functional Equivalence from the perspective of culture with the effective and flexible method, which is of great help to spread Chinese culture.

\section{References}

Du, Feiba, \& Du, Minglu. (2007). Marvels of China. Beijing: China Travel and Tourism Press.

Du, Jiang. (2006). Panoramic China - Sichuan land of natural abundance. Beijing: Foreign Language Press.

Gong, Jiansheng, \& Zhang, Ying. (2006). Panoramic China - Tianjin lustrous pearl of the Bohai gulf. Beijing: Foreign Language Press.

He, Shizhong. (2006). Panoramic China - Chongqing mystical three gorges and glamorous municipality. Beijing: Foreign Language Press.

Juliet, B. (2009). Peking - A historical and intimate description of its chief places of interest. Shanghai: Foreign Language Teaching and Research Press.

Lin, Yuhua. (2008). A study of the translation of names of scenic spots from the perspective of culture. Fuzhou: College of Foreign Languages, Fujian Normal University.

Luo, Weixuan. (2004). China splendors panorama of China's world heritage. Changsha: Hunan Map Press.

Nida, E. A. (1995). Language, culture, and translating. Shanghai: Shanghai Foreign Language Education Press.

Nida, E. A. (2003). Contexts in translating. Amsterdam: John Benjamin’s Publishing Company.

Xiang, Jinke. (2006). Panoramic China - Hebei the Great Wall legacy. Beijing: Foreign Language Press.

Yu, Changjiang. (2007). The basis of national tour. Beijing: Beijing Yanshan Press.

Zhang, Kan, \& Hu, Changshun. (2007). World heritage in China. Guangdong: South China University of Technology Press. 